\title{
Quantification of Root and Stem Colonization of Watermelon by Fusarium oxysporum f. sp. niveum and Its Use in Evaluating Resistance
}

\author{
X. G. Zhou and K. L. Everts
}

First author: University of Maryland, 27664 Nanticoke Road, Salisbury 21801; and second author: University of Maryland, Salisbury, with joint appointment with the University of Delaware, 16684 County Seat Highway, Georgetown 19947.

Accepted for publication 26 March 2004.

\begin{abstract}
Zhou, X. G., and Everts, K. L. 2004. Quantification of root and stem colonization of watermelon by Fusarium oxysporum f. sp. niveum and its use in evaluating resistance. Phytopathology 94:832-841.

Colonization of watermelon root and stem tissues by Fusarium oxysporum $\mathrm{f}$. sp. niveum race 1 and its relationship to the apparent resistance to Fusarium wilt was investigated. In each of 2 years, 17 differentially susceptible watermelon cultivars and one accession were tested in the greenhouse, and 7 cultivars also were tested in the field. Colonization by a chlorate-resistant marked isolate of the fungus was assayed by plating homogenized tissue samples on a selective medium. Six days after inoculation, seedlings of highly resistant, moderately resistant, and susceptible

$(Y)$ of the seedlings was positively correlated with colonization $(X)$ by F. oxysporum f. sp. niveum race 1 in roots $\left(Y=21.2 \ln [X+1]-140.7, R^{2}=\right.$ $0.85)$ or lower stems $\left(Y=17.3 \ln [X+1]-78.6, R^{2}=0.86\right)$. Percent wilt $(Y)$ also was correlated with the ratio $\left(X_{\mathrm{r}}, 0\right.$ to 1 values) of lower stem to root colonization $\left(Y=34 \ln X_{\mathrm{r}}+112, R^{2}=0.36\right)$. Field evaluations confirmed these relationships, and a link between cultivar resistance and a reduced rate of spread of the fungus in primary stems during a season was observed. Fruit yield decreased with increased tissue colonization at linear rates of 9.9 to $12.7 \mathrm{t} / \mathrm{ha}$ per $\ln (\mathrm{CFU} / \mathrm{g}+1)\left(R^{2} \geq 0.58\right)$. The greenhouse seedling stem colonization assay described may be utilized as a collaborative method to quantify Fusarium wilt resistance in watermelon.
\end{abstract} cultivars had $F$. oxysporum $\mathrm{f}$. sp. niveum race $1 \mathrm{CFU}$ counts in the lower stems of $10^{2}, 10^{3}$, and $10^{4} \mathrm{CFU} / \mathrm{g}$ of fresh tissue, respectively. Percent wilt
Additional keyword: Citrullus lanatus.
Fusarium oxysporum Schlechtend.:Fr. f. sp. niveum (E. F. Sm.) W. C. Synder \& H. N. Hans., casual agent of Fusarium wilt of watermelon (Citrullus lanatus (Thunb.) Matsum. \& Nakai), is the most important soilborne pathogen limiting watermelon production in many areas of the world (25). Effective management of the disease is primarily dependent on the use of resistant cultivars (25). Three races of $F$. oxysporum f. sp. niveum have been described: races 0,1 , and $2(24,27,33)$. Most watermelon cultivars have resistance to race 0 ; thus, race 0 has little economic significance (27). Race 2 is highly aggressive and can overcome resistance in all current commercial cultivars. The known geographic distribution of race 2 is limited to five states in the United States: Delaware (42), Florida (27), Oklahoma (4), Maryland (42), and Texas (24). In contrast, race 1, the most prevalent of the three races, occurs throughout the watermelon-growing regions of the United States and the world $(3,25,27,43)$. Resistance to race 1 has been attributed to a single dominant gene $(15,16,34)$. 'Summit' was the first watermelon cultivar in which a single dominant gene controlling resistance to race 1 was demonstrated (16), followed by cv. Calhoun Gray (34) and plant introduction (PI) accession 296341-FR (15). However, cultivars resistant to race 1 react in a continuum from highly resistant to moderately resistant when resistance is rated based on incidence and severity of wilt symptoms induced by race $1(3,8,28)$. No quantitative investigation has been conducted to relate race 1 resistance in watermelon to internal plant colonization by $F$. oxysporum f. $\mathrm{sp}$. niveum. Better knowledge of this relationship would improve our understanding of the mechanism of resistance and lead to the improve-

Corresponding author: K. L. Everts; E-mail address: keverts@umd.edu

Publication no. P-2004-0604-01R

(c) 2004 The American Phytopathological Society ment of methods to evaluate genetic resistance or induced resistance in watermelon.

Correlations between vascular colonization and Fusarium wilt resistance have been documented on many crops $(7,9,10,13,29$, 30,36). Watermelon (30) and summer squash (Cucurbita pepo var. melopepo) (29) infected by $F$. oxysporum $\mathrm{f}$. sp. niveum, muskmelon (Cucumis melo) infected by F. oxysporum f. sp. melonis $(10,13,36)$, and tomato (Lycopersicon esculentum) infected by F. oxysporum f. sp. lycopersici $(7,9,39)$ or by $F$. oxysporum f. sp. pisi (9) exhibited a correlation between vascular colonization and Fusarium wilt. However, these investigations were limited to the qualitative relationship between colonization and wilt. Additionally, pathogenic forms of $F$. oxysporum are able to penetrate and colonize inoculated nonhost species inducing no wilt, but the extent of colonization is generally lower than in their corresponding hosts $(6,11-13,19)$.

The frequency of colonization of plant tissues by $F$. oxysporum $(10,13,18,21-23)$ and the extent of colonization $(7,12,38,39)$ has been evaluated. Frequency of colonization is measured by counting the number of sites along a given length of root or stem that produce discrete colonies on isolation medium. Extent of colonization is the extent of pathogen growth in plant tissues measured by spreading homogenized suspension of a given weight of roots or stems on a semi-selective medium. Elgersma et al. (7) suggested that the latter method is a more accurate measurement of tissue colonization because it accounts for the actual amount of viable fungus within host plants. Clear correlations between tissue colonization and wilt resistance have been established in some studies using this enumeration technique $(7,9,39)$.

The inability to distinguish $F$. oxysporum f. sp. niveum from other $F$. oxysporum formae speciales and from nonpathogenic isolates of $F$. oxysporum based on morphology is another impediment to defining the relationship between pathogen colonization 
and wilt resistance, especially under field conditions. Hadar et al. (14) reported the use of chlorate-resistant mutants (nitrate-nonutilizing) and a selective medium to monitor the population of pathogenic isolates of $F$. oxysporum, facilitating more accurate detection of artificially infested pathogen populations in plants and soils.

Fusarium wilt resistance traditionally is measured by incidence and severity of symptoms of Fusarium wilt in plants, weight and growth of infected plants, or yield and quality of fruit $(1,41)$. However, external foliar symptoms of Fusarium wilt were not a good measure of resistance in some crops like cowpea (Vigna unguiculata) (40). Genotype characteristics, environmental factors, presence of multiple races, and other pathogens or pests influence weight and growth of plants and yield and quality of fruit in field evaluations. Evaluation of external symptoms is time-consuming, and sometimes inconclusive $(3,27)$. In contrast, quantitative estimation of colonization by a Fusarium wilt pathogen in controlled environmental conditions may avoid or minimize these disadvantages, and may aid traditional pathogenicity screening tests for resistance evaluation. Quantitative description also may give important information about vascular invasion by the Fusarium wilt fungus.

The objectives of this study were to (i) characterize watermelon root and stem colonization by race 1 of $F$. oxysporum f. sp. niveum and its relationship to wilt resistance under greenhouse and field conditions and (ii) explore the potential for using a greenhouse seedling colonization assay to evaluate Fusarium wilt resistance in watermelon. A bioassay for measuring the extent of pathogen colonization and a pathogenic, chlorate-resistant marked isolate of $F$. oxysporum f. sp. niveum race 1 were used in this study. Preliminary reports of this work have been published (44-46).

\section{MATERIALS AND METHODS}

Generation and characterization of chlorate-resistant marked pathogen isolates. A pathogenic, chlorate-resistant marked isolate was derived from a wild-type isolate of $F$. oxy- sporum f. sp. niveum race 1 . The wild-type isolate (F-030-1) was isolated from a wilted watermelon in Maryland in 2000 (43). Chlorate-resistant mutants were generated by transferring the parent wild-type isolate grown on potato dextrose agar (PDA) onto a minimal medium (MM) amended with $\mathrm{KClO}_{3}$ at $15 \mathrm{~g} / \mathrm{liter}$ (MMC) (35), followed by incubation for 7 to 10 days at room temperature under $12 \mathrm{~h}$ of florescent light per day. Portions of the fast-growing sectors around colonies were placed on MM and PDA media. Those that produced thin, expansive growth with no aerial mycelium on MM but showed wild-type growth with aerial mycelium on PDA were considered to be chlorate-resistant mutants (also nitrate-nonutilizing mutants). These mutants were further transferred to MMC supplemented with pentachloronitrobenzene ( $0.5 \mathrm{~g}$ a.i./liter), chloramphenicol (250 mg/liter), and $85 \%$ lactic acid $(0.6 \mathrm{ml} /$ liter) as a selective medium (MMCPA) for growth of chlorate-resistant mutants (14). Chlorate-resistant strains obtained by this procedure were tested for pathogenicity on the susceptible watermelon cv. Sugar Baby. Chlorate-resistant strains were recovered on MMCPA medium from the wilted plants. Six single-spore isolates derived from these strains were tested for pathogenicity, their growth in soil, and their growth on PDA. One of the isolates with characteristics similar to the wildtype progenitor isolate was used in the subsequent greenhouse and field experiments. In addition, the mutant isolate was vegetatively compatible with tester mutant strains of a standard reference race 1 of $F$. oxysporum f. sp. niveum (ATCC 44293).

Greenhouse evaluation. Seventeen diploid cultivars and one PI accession of watermelon (Table 1) were evaluated in the greenhouse using a root-dip inoculation technique (27). The cultivars and accession represented a wide range of resistance to race 1 of F. oxysporum f. sp. niveum $(2,8,28,30,43)$. Each cultivar and accession was seeded in 128-cell trays containing a pasteurized vermiculite:peat moss $(2: 3, \mathrm{vol} / \mathrm{vol}$ mixture) growth medium (Scotts-Sierra Horticultural Products Co., Maryville, OH). Plants were maintained in a greenhouse at 20 to $29^{\circ} \mathrm{C}$, using a Horticultural Environment Controller (Model Step 50A; Vadsworth

TABLE 1. Root and stem colonization of 17 cultivars and one accession (PI 296341-FR) of watermelon by Fusarium oxysporum f. sp. niveum, incidence of Fusarium wilt, and resistance rating in each of two experiments under greenhouse conditions

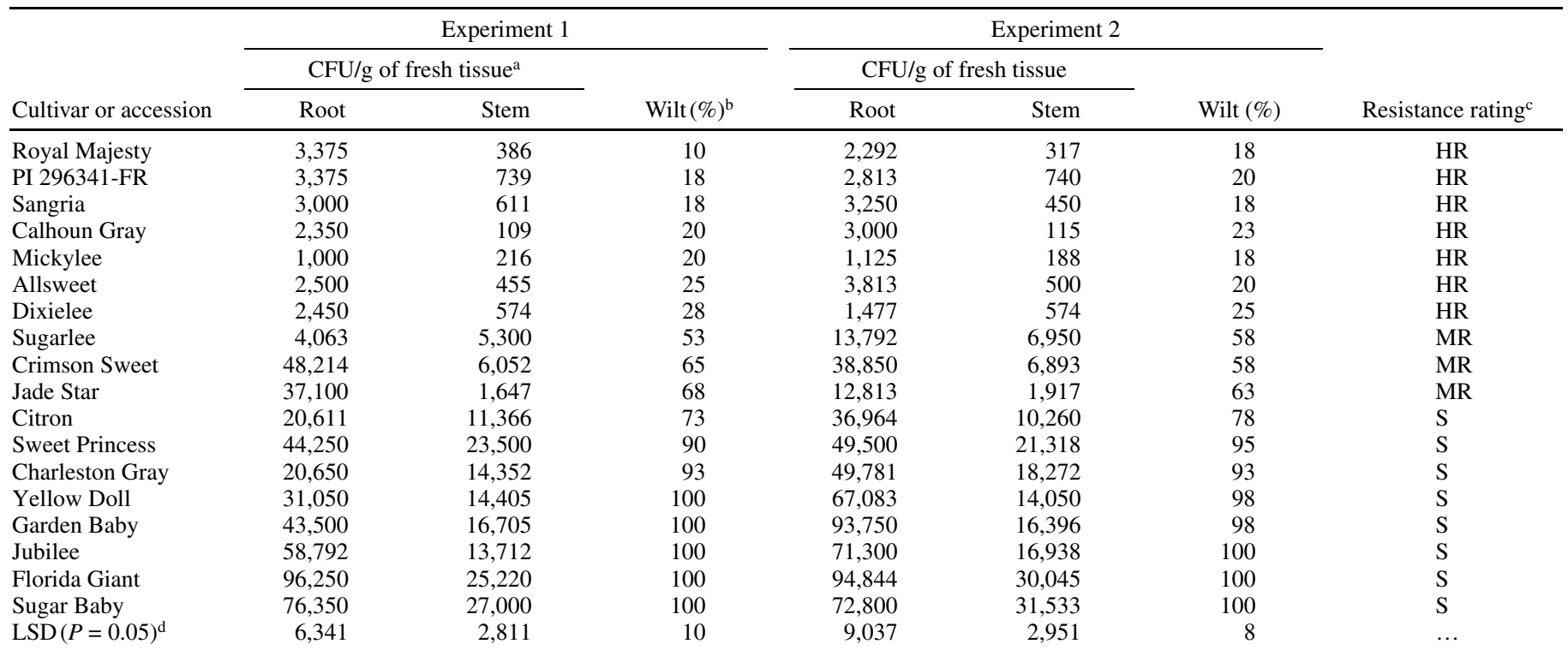

${ }^{a}$ Means of four replicates; the value for each replicate was the average number of Fusarium colonies on four plates containing chlorate-resistant selective medium (minimal medium amended with $\mathrm{KClO}_{3}$ at $7.5 \mathrm{~g} /$ liter and supplemented with pentachloronitrobenzene [0.5 g a.i./liter], chloramphenicol [250 mg/liter], and $85 \%$ lactic acid $[0.6 \mathrm{ml} / \mathrm{liter}]$ ). Plates were spread with diluted suspensions of homogenized root or stem tissues of plants (four plants/replicate) that were root-dip inoculated with the culture of a race 1 chlorate-resistant marked isolate of $F$. oxysporum f. sp. niveum and were grown for 6 days.

${ }^{\mathrm{b}}$ Means of four replicate pots; each pot had 10 plants. The percentage of plants showing symptoms of Fusarium wilt was assessed 21 days after inoculation.

${ }^{\mathrm{c}}$ Resistance ratings were assigned for cultivars or the accession based on their average percent wilt over two experiments, where HR $=$ highly resistant $(\leq 33 \%$ wilt), MR = moderately resistant ( 34 to $65 \%$ wilt), and $\mathrm{S}=$ susceptible ( $\geq 66 \%$ wilt)

${ }^{\mathrm{d}}$ Means were separated according to Fisher's protected least significant difference (LSD) test at $P=0.05$. Prior to analysis, colonization data were transformed to $\ln (\mathrm{CFU} / \mathrm{g}$ of tissue +1$)$, and percent wilt data were transformed into the arcsine of the square root of the proportion of wilt. 
Control System, Inc., Arvada, CO). Seedlings were watered and fertilized as needed to maintain normal growth.

Seedlings were carefully uprooted 2 weeks after seeding and washed in tap water to remove soil particles. In all, 56 seedlings of each cultivar and accession, which were uniform in growth and undamaged when uprooted, were separated into four groups of 14 seedlings each. Roots of each of the 14-seedling groups were dipped for $30 \mathrm{~s}$ in a microconidial suspension (approximately $1 \times$ $10^{6}$ microconidia/ml) from the race 1 chlorate-resistant marked isolate of $F$. oxysporum $\mathrm{f}$. sp. niveum. The inoculated seedlings were carefully replanted in $100-\mathrm{cm}^{3}$ pots (14 seedlings/pot), containing the same growth medium described above. The microconidial suspension used for inoculation was prepared by harvesting microconidia from a 7- to-10-day-old liquid salts medium (33) grown on a rotary shaker $(80 \mathrm{rpm} / \mathrm{min})$ at room temperature. The inoculum was filtered through eight layers of cheesecloth and adjusted to the desired concentration with the aid of a Spencer hemacytometer. Seedlings of each cultivar and accession were dipped into 1:3 diluted, sterilized liquid salts medium that served as mock inoculum. There were four replicate pots for each inoculum-cultivar combination. All pots were arranged on greenhouse benches in a randomized complete block design.

The extent of colonization by $F$. oxysporum $\mathrm{f}$. sp. niveum in the root and lower stem tissues of inoculated plants was determined 6 days after inoculation. This was within the range of sampling time previously reported for adequately differentiating levels of colonization by Fusarium wilt pathogens between susceptible and resistant hosts $(6,39)$. This also was the time at which first symptoms of Fusarium wilt occurred on susceptible cultivars in the current experiments. Four plants randomly selected from each pot were carefully removed, and the roots washed in running tap water to remove soil particles. The foliage of the plants was removed, and the remaining parts were surface disinfected with $6 \% \mathrm{NaOCl}$ for $1 \mathrm{~min}$, rinsed in running tap water four times, and washed a final time in sterilized water. The samples were blot dried with paper towels and aseptically separated into root systems, and stem portions $5 \mathrm{~cm}$ long from the crown node. The root and stem samples were further cut into approximately $10-\mathrm{mm}$ long pieces with a sterile surgical blade, weighed, and homogenized in $50 \mathrm{ml}$ of sterile water at low, then high, speed for $1 \mathrm{~min}$ each at grind position with an Osterizer blender (14-speed model; Goodman's Co., Miami). The resulting suspensions were filtered through eight layers of cheesecloth. One millimeter of undiluted tissue homogenate and of a 1:10 dilution with $0.1 \%$ sterilized water agar, when being disturbed on a magnet stirrer or a rotational mixer, was plated on MMCPA medium amended with $\mathrm{KClO}_{3}$ at $7.5 \mathrm{~g} /$ liter. This medium selectively allows growth of chlorate-resistant mutants (14). Colonies on the medium were counted after 10 to 15 days at room temperature, and counts converted to $\mathrm{CFU} / \mathrm{g}$ of root or stem fresh weight. There were two plates for each dilution and four plates for each replicate pot.

The number of seedlings showing symptoms of Fusarium wilt (yellowing, stunting, or wilting) in each pot was counted weekly until the conclusion of the experiment, 21 days after inoculation. The experiment was conducted twice.

The resistance rating for each cultivar and accession was based on average percent wilt over the two experiments. Cultivars or the accession were rated (i) susceptible if average wilt incidence was $\geq 66 \%$, (ii) moderately resistant if average wilt incidence ranged from 34 to $65 \%$, or (iii) highly resistant if average wilt incidence was $\leq 33 \%$.

Field evaluation. The greenhouse results were verified in field experiments that were conducted in 2001 and 2002. The experi-

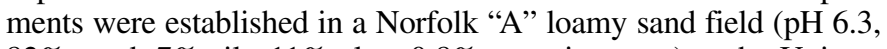
$82 \%$ sand, $7 \%$ silt, $11 \%$ clay, $0.8 \%$ organic mater) at the University of Maryland Lower Eastern Shore Research and Education Center, Salisbury, MD. No watermelons had been grown in the field for the past 20 years. In April 2001, 20 soil samples randomly collected within the field were determined to be free of F. oxysporum f. sp. niveum by soil dilution plating on Komada's medium (20) and greenhouse pathogenicity tests of randomly selected colonies of $F$. oxysporum with the procedure described previously (43). The detection threshold for this assay was approximately $10 \mathrm{CFU} / \mathrm{g}$ of dry soil. Wheat was cropped to the field as a winter cover crop in each year. Herbicides and insecticides were applied as necessary to manage the watermelon crop (31).

In 2001, seven watermelon cultivars that ranged in order from susceptible to highly resistant to $F$. oxysporum f. sp. niveum race 1 , based on the results of the greenhouse experiments, were evaluated: Florida Giant, Sugar Baby, Crimson Sweet, Charleston Gray, Sugarlee, Dixielee, and Royal Majesty. Four-week-old greenhouse seedlings of each cultivar were transplanted $0.9 \mathrm{~m}$ apart within rows on 18 June in a randomized complete block design with four replicates. Plots consisted of single raised beds $15 \mathrm{~cm}$ high and $9.1 \mathrm{~m}$ long on 1.8-m centers. Soybean rows were planted in 1-m-wide areas that separated adjacent plots and also were planted on all sides of the field as a border. Two weeks after transplanting, a 20 - $\mathrm{ml}$ microconidial suspension $\left(3.5 \times 10^{5}\right.$ microconidia/ml) from the race 1 chlorate-resistant marked isolate of F. oxysporum f. sp. niveum was poured into a hole (approximately $2 \mathrm{~cm}$ in diameter and $8 \mathrm{~cm}$ in depth) $7 \mathrm{~cm}$ away from the crown of each plant and the hole was filled with soil. Preparation of the inoculum was the same as described for the greenhouse tests.

The extent to which $F$. oxysporum $\mathrm{f}$. sp. niveum colonized the roots, crowns, and lower stems of each cultivar was determined at the end of the cropping season. Three plants were selected randomly from the remaining live plants that showed symptoms of Fusarium wilt in each plot on 20 August (45 days after inoculation), and their root systems were carefully excavated with a shovel. The foliage of these plants was removed, and the remaining root systems, crown, and lower stem portions were washed in running tap water, surface disinfected with $6 \% \mathrm{NaOCl}$ for $2 \mathrm{~min}$, and rinsed in running tap water five times. The treated samples were aseptically separated into roots, crown portions, and stem (10 $\mathrm{cm}$ long from the crown node) portions. Each tissue portion was cut further into approximately 10 -mm-long pieces with a paper cutter. After each use, the cutter was disinfected with $75 \%$ ethanol. Each type-tissue $(10 \mathrm{~g})$ randomly collected from pooled pieces of the same type-tissue was homogenized in $300 \mathrm{ml}$ of sterile water at low, then high, speed for 1 min each with a blender as described previously. The resulting suspensions were filtered through eight layers of cheesecloth and adjusted to $300 \mathrm{ml}$ with sterilized water. One millimeter of undiluted tissue homogenate and of a 1:10 dilution with $0.1 \%$ sterilized water agar was evenly spread over plates containing MMCPA medium. Colonies were counted and counts converted into $\mathrm{CFU} / \mathrm{g}$ of fresh tissue. There were two plates for each dilution and four plates for each plot.

The number of plants showing symptoms of Fusarium wilt (yellowing, stunting, or wilting) was assessed weekly following inoculation, and wilt incidence obtained on 20 August is presented. Marketable watermelon fruit were individually weighed on 24 August.

In 2002, the experiment was repeated in the same field used in 2001. The seven same cultivars were evaluated, except that Sangria replaced Florida Giant. Transplants were planted on 11 June and inoculated on 24 June. Disease incidence was assessed and plant samples for colonization assay were collected on 6 August, and marketable fruit were harvested on 13 August. Procedures for inoculum preparation, pathogen inoculation, plant sampling, colonization assay, and disease incidence assessment were the same as those used in 2001.

Distribution of $F$. oxysporum f. sp. niveum in field-grown plant stems. Longitudinal distribution of $F$. oxysporum $\mathrm{f}$. sp. niveum in the primary stems of field-grown plants was determined at the end of the season in 2001 and 2002 for three 
selected cultivars. Sugar Baby, Sugarlee, and Royal Majesty were susceptible, moderately resistant, and highly resistant, respectively, to race 1 of $F$. oxysporum $\mathrm{f}$. sp. niveum. Three plants were collected randomly from the remaining live plants in each plot as described previously. All the lateral stems and leaves of the plants were removed, and the remaining primary stems were washed and surface disinfected as described previously for field root, crown, and stem samples. The primary stems then were cut aseptically into successive cross sections at $10-\mathrm{cm}$ intervals from the base of stems to the top. Plant materials from the same cross sections were pooled, weighed, and cut into approximately $10-\mathrm{mm}-$ long pieces and assayed as described previously. Colonies of F. oxysporum f. sp. niveum on MMCPA medium were counted, and counts converted to $\mathrm{CFU} / \mathrm{g}$ of fresh stem weight for successive stem sections to establish a continuing distribution of pathogen colonization within plants from the base of stems to the top.

Data analysis. Analysis of variance (ANOVA) was used to test for significant differences in the extent of tissue colonization, incidence of Fusarium wilt, fruit yield, and interactions of experiment-cultivar in greenhouse and field experiments. Means were compared using Fisher's protected least significant difference (LSD) test. Colonization data were transformed into $\ln (\mathrm{CFU} / \mathrm{g}$ tissue +1$)$ prior to analysis, and percent wilt data transformed into the arcsine of the square root of the proportion of wilt to stabilize variances (37); nontransformed data are presented.

Means for the wilt incidence response variable ( $Y$, percent wilt) were from four replicate pots or plots of each cultivar in each of the greenhouse and field experiments. The correlation between wilt incidence and root or lower stem colonization (X, CFU/g of tissue) by $F$. oxysporum f. sp. niveum across all cultivars was evaluated by a logarithmic equation of the form

$$
Y=a \ln (X+1)+b
$$

in which $a$ characterized the curvilinear rate of the increase of wilt incidence with the increase of colonization in respective tissues, $\left(\left[d_{\mathrm{y}} / d_{\mathrm{x}}\right] /[X+1]\right)$, (percent wilt per $\ln [\mathrm{CFU} / \mathrm{g}$ tissue $]$ ), and $b$ was the constant parameter (percent wilt), specifying location of disease level when colonization by $F$. oxysporum $\mathrm{f}$. $\mathrm{sp}$. niveum was not detected (assuming $X=0 \mathrm{CFU} / \mathrm{g}$ of tissue).

The relationship between colonization $(X, \mathrm{CFU} / \mathrm{g}$ tissue) in root or lower stem tissues and marketable fruit yield $\left(Y_{\mathrm{f}}\right.$, ton/ha) was assessed for the field experiments of 2001 and 2002 using a linear model. The model is

$$
Y_{\mathrm{f}}=a_{\mathrm{f}} X^{\prime}+b_{\mathrm{f}}
$$

in which $X^{\prime}=\ln (X+1)$, the natural logarithmic link function to generalize a linear scale for the model, and $a_{\mathrm{f}}$ and $b_{\mathrm{f}}$ were the parameters that characterized the linear rate of the decrease of fruit yield with increasing colonization ( $\mathrm{t} / \mathrm{ha}$ per $\ln [\mathrm{CFU} / \mathrm{g}$ of tissue +1$]$ ) and the upper limit of fruit yield (t/ha), respectively.

The longitudinal distribution of $F$. oxysporum $\mathrm{f}$. sp. niveum in the primary stems of watermelon plants under field conditions in 2001 and 2002 was evaluated using an equation with the form

$$
Y_{\mathrm{c}}=a_{\mathrm{c}} S+b_{\mathrm{c}}
$$

in which $Y_{\mathrm{c}}$ was the relative colonization (percent colonization), which was used to indicate the relative pathogen density in a specific stem section in each year. A value for $Y_{\mathrm{c}}$ was calculated by dividing the average value of colonization at a specific stem section by the average value of the greatest colonization observed within each year, and multiplied by 100 . All colonization data were transformed into $\ln (\mathrm{CFU} / \mathrm{g}$ tissue +1$)$ prior to computation. $S$ was the distance $(\mathrm{cm})$ at which colonization occurred on the primary stems of plants from the base of stems, and the parameters $a_{\mathrm{c}}$ and $b_{\mathrm{c}}$ were the steepness of colonization gradient (slope) that characterized the linear rate of the decrease of relative colonization with the increase of distance from the base of stems (per- cent colonization per $\mathrm{cm}$ ) and the upper limit of relative colonization (percent colonization), respectively.

To characterize the correlation between the ratio of lower stem to root colonization and apparent wilt resistance under greenhouse and field conditions, percent wilt data ( $Y$, percent wilt) were plotted against the ratios $\left(X_{\mathrm{r}}, 0\right.$ to 1 values in theory). The ratios were computed by dividing the average value of colonization for lower stem tissues (5 and $10 \mathrm{~cm}$ long from the crown node for greenhouse and field-grown plants, respectively) by the average value of colonization for root tissues of the same plants assayed. The functional relationship was defined by the equation

$$
Y=a_{\mathrm{r}} \ln X_{\mathrm{r}}+b_{\mathrm{r}}
$$

in which $a_{\mathrm{r}}$ and $b_{\mathrm{r}}$ were the parameters that characterized the curvilinear rate of the increase of wilt incidence with the increase of the ratio of lower stem to root colonization, $\left(\left[d_{\mathrm{y}} / d_{\mathrm{x}}\right] / X_{\mathrm{r}}\right)$, (percent wilt per unit of $\ln$ [ratio]), and the upper limit of wilt incidence (percent wilt), respectively.
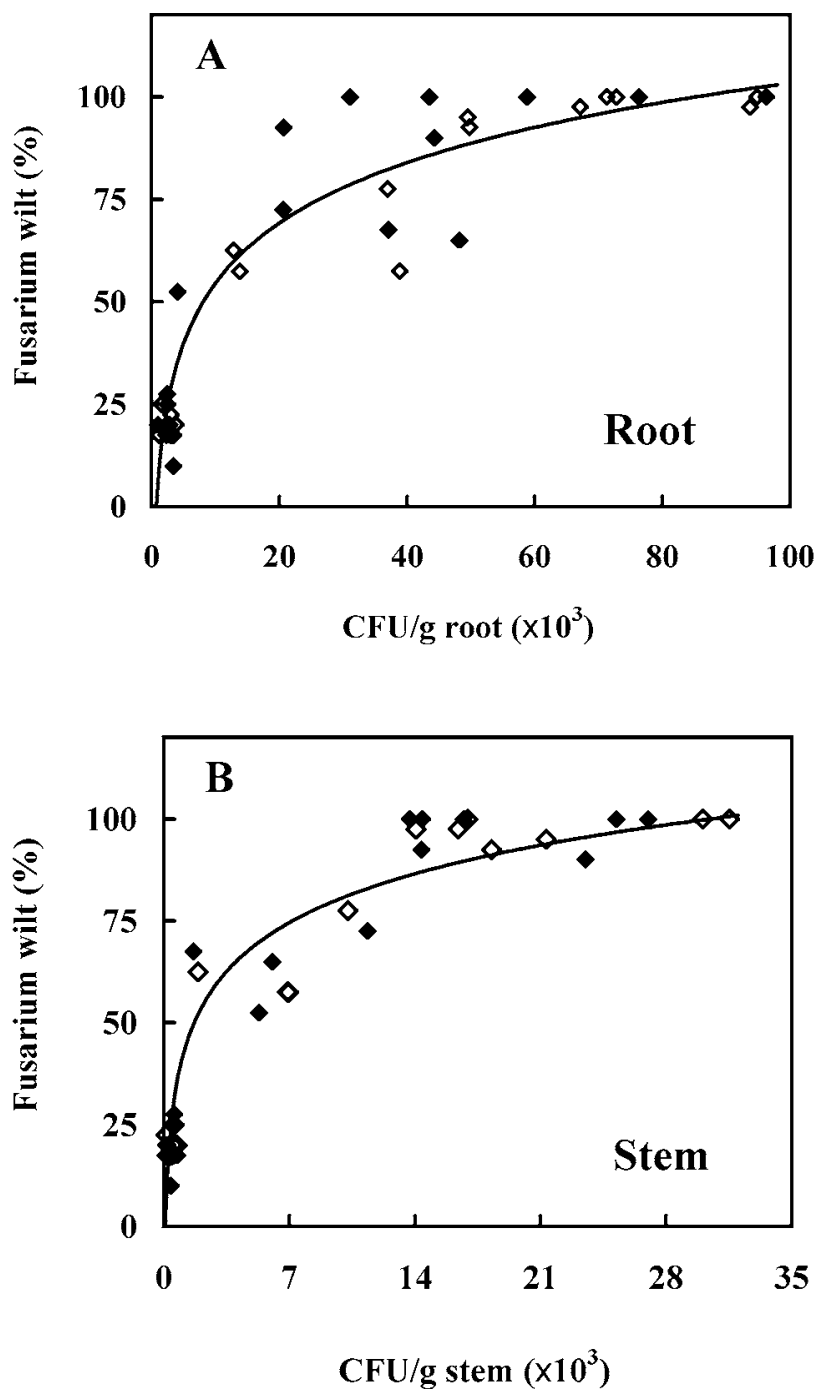

Fig. 1. Relationship between colonization $(X)$ in the $\mathbf{A}$, roots or $\mathbf{B}$, lower stems of 17 cultivars and one accession of watermelon by Fusarium oxysporum $\mathrm{f}$. sp. niveum and incidence of Fusarium wilt $(Y)$ under greenhouse conditions. Observed values for experiments $1(\diamond)$ and $2(\diamond)$ are the means of four replicate pots, each consisting of 14 plants. Among these plants, four were sampled randomly at 6 days after root-dip inoculation with the culture of a race 1 chlorate-resistant marked isolate of $F$. oxysporum f. sp. niveum, and assayed for vascular colonization on a selective medium. The remaining 10 plants were assessed at 21 days after inoculation for the percentage of plants showing symptoms of Fusarium wilt. Regression equations (curves) are: root, $Y=21.2$ $\ln (X+1)-140.7\left(R^{2}=0.85\right)$; and stem, $Y=17.3 \ln (X+1)-78.6\left(R^{2}=0.86\right)$. 
For each equation, parameters were estimated directly by simple linear regression with PROC REG. In each regression, goodness of fit was evaluated by coefficients of determination and standard errors on parameter estimates, and also checked by inspection of observed values and predicted values of the dependent variables plotted against independent variables $(32,37)$. Heteroscedasticity was evaluated by inspection of standardized residual errors plotted against predicted values $(32,37)$. All statistic analyses were performed with the Statistical Analysis System (SAS System for Windows, release 8.0; SAS Institute, Cary, NC).

\section{RESULTS}

Greenhouse evaluation. Percentage of plants showing symptoms of Fusarium wilt in all 17 cultivars and accession was associated directly with the degree of colonization by $F$. oxysporum $\mathrm{f}$. sp. niveum in each of two experiments (Table 1). Colonization data always were low $(<1,000 \mathrm{CFU} / \mathrm{g}$ of fresh tissue) in the lower stems $(5 \mathrm{~cm}$ long from the crown node) of the first six highly resistant cultivars and one accession, intermediate (between 1,000 and $10,000 \mathrm{CFU} / \mathrm{g}$ fresh tissue) in the next three moderately resistant cultivars, and high ( $>10,000 \mathrm{CFU} / \mathrm{gm}$ fresh tissue) in the last eight susceptible cultivars. A similar trend was observed for root tissues. However, the separation of cultivar resistance was not as clear as by colonization data in lower stem tissues. A pattern of higher CFU/g of tissue in roots than those in lower stems was observed for all but one cultivar (Sugarlee in experiment 1) and accession evaluated. No symptoms of Fusarium wilt and pathogen colonization in noninoculated control plants were observed.

Percent wilt was quantitatively correlated with colonization in both root and lower stem tissues (Fig. 1), and the relationship was defined by equation $1(Y=a \ln [X+1]+b)$. Parameters of this equation were estimated from data pooled from two experiments because differences in estimates of the parameters $a$ and $b$ for each tissue type between experiments were small (Table 2). Additionally, experiment-cultivar interactions for percent wilt also were insignificant $(P=0.76)$. More than $85 \%$ of the variation in percent wilt was explained by the effect of colonization in plant tissues. Parameter $a$ of equation 1 adequately characterized the constant, curvilinear rate of increase in percent wilt with colonization. However, the effect was greatest in lower CFU/g of tissue, then slowed and reached an apparent upper limit in higher CFU/g of tissue in each tissue type (Fig. 1). The instantaneous rate of increase in percent wilt $\left(\left[d_{\mathrm{y}} / d_{\mathrm{x}}\right]=a /[X+1]\right)$ was greatest in lower $\mathrm{CFU} / \mathrm{g}$ of tissue. For example, at $200 \mathrm{CFU} / \mathrm{g}$ of tissue in lower stems, percent wilt increased at an instantaneous rate of $0.0861 \%$ wilt per CFU/g of tissue. At 2,000 CFU/g of tissue, the instantaneous rate declined 10 -fold to only $0.0086 \%$ wilt per CFU/g of tissue. At colonization greater than 20,000 CFU/g of tissue, the instantaneous rate was less than $0.0009 \%$ wilt per $\mathrm{CFU} / \mathrm{g}$ of tissue. At colonization of 634 and 4,027 CFU/g of fresh tissue in the lower stem tissue, predicted percent wilt was 33 and $65 \%$, re-

TABLE 2. Parameter estimates for the logarithmic equation $Y=a \ln (X+1)+b$ that characterized the relationship between root or stem colonization by Fusarium oxysporum f. sp. niveum and incidence of Fusarium wilt in watermelon in each of two greenhouse experiments as well as for pooled data from the two experiments ${ }^{\mathrm{a}}$

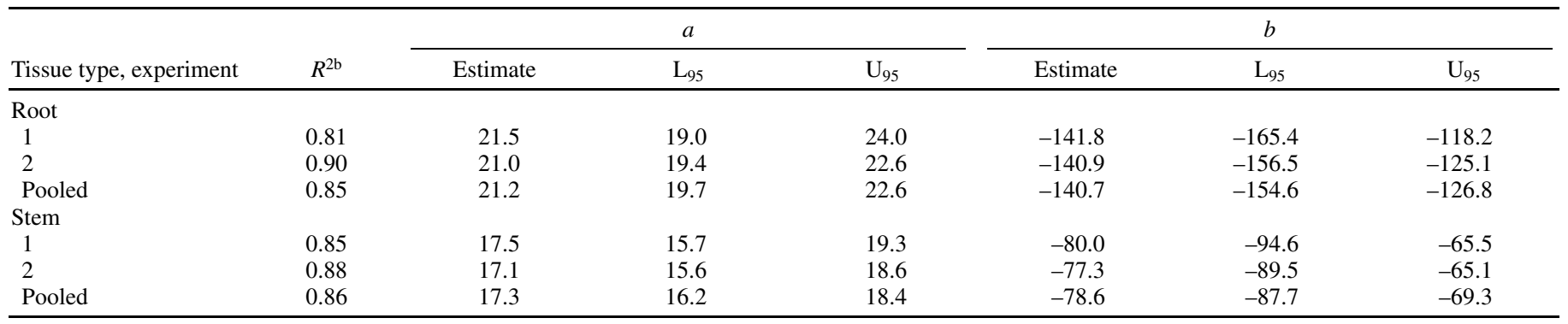

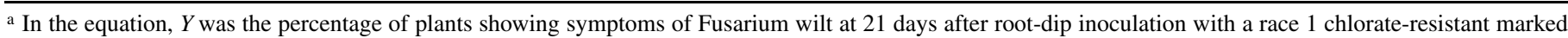
isolate of $F$. oxysporum f. sp. niveum, $X$ was colonization in root or lower stem tissues (CFU/g of fresh tissue) at 6 days after inoculation, and $a$ and $b$ were the curvilinear rate of wilt increase with respect to colonization (percent wilt per $\ln [\mathrm{CFU} / \mathrm{g}$ tissue +1$]$ ) and the constant parameter (percent wilt), respectively. Estimate, $\mathrm{L}_{95}$, and $\mathrm{U}_{95}$ are the parameter estimate and the associated lower and upper $95 \%$ limits about the estimate, respectively.

b Coefficient of determination.

TABLE 3. Root, crown, and lower stem colonization of eight watermelon cultivars by Fusarium oxysporum f. sp. niveum, and incidence of Fusarium wilt in each of two years under field conditions

\begin{tabular}{|c|c|c|c|c|c|c|c|c|}
\hline \multirow[b]{3}{*}{ Cultivar } & \multicolumn{4}{|c|}{2001} & \multicolumn{4}{|c|}{2002} \\
\hline & \multicolumn{3}{|c|}{$\mathrm{CFU} / \mathrm{g}$ of fresh tissue ${ }^{\mathrm{a}}$} & \multirow[b]{2}{*}{ Wilt $(\%)^{\mathrm{b}}$} & \multicolumn{3}{|c|}{$\mathrm{CFU} / \mathrm{g}$ of fresh tissue } & \multirow[b]{2}{*}{ Wilt (\%) } \\
\hline & Root & Crown & Stem & & Root & Crown & Stem & \\
\hline Sangria & $\ldots$ & $\ldots$ & $\ldots$ & $\ldots$ & 3,600 & 1,125 & 825 & 5 \\
\hline Dixielee & 6,082 & 6,827 & 6,619 & 31 & 17,625 & 2,175 & 150 & 10 \\
\hline Charleston Gray & 7,914 & 5,088 & 573 & 33 & 6,075 & 1,275 & 600 & 18 \\
\hline Crimson Sweet & 1,092 & 186 & 265 & 39 & 2,100 & 600 & 375 & 8 \\
\hline Florida Giant & 85,432 & 33,028 & 66,767 & 100 & $\ldots$ & $\ldots$ & $\ldots$ & $\ldots$ \\
\hline $\operatorname{LSD}(P=0.05)^{\mathrm{c}}$ & 5,948 & 4,178 & 3,490 & 8 & 16,043 & 2,521 & 1,742 & 9 \\
\hline
\end{tabular}

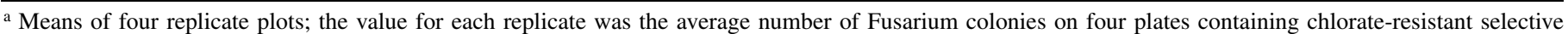
medium (minimal medium amended with $\mathrm{KClO}_{3}$ at $7.5 \mathrm{~g} /$ liter and supplemented with pentachloronitrobenzene [0.5 $\mathrm{g}$ a.i./liter], chloramphenicol [250 mg/liter], and $85 \%$ lactic acid [0.6 ml/liter]). Plates were spread with diluted suspensions of homogenized root, crown, or lower stem tissues of plants (3 plants/plot) that were randomly collected 45 days after inoculation. Plants were individually inoculated with the culture of a race 1 chlorate-resistant marked isolate of F. oxysporum f. sp. niveum 2 weeks after transplanting; ... = not evaluated.

${ }^{\mathrm{b}}$ Means of four replicate plots; the percentage of plants showing symptoms of Fusarium wilt was assessed prior to fruit harvest.

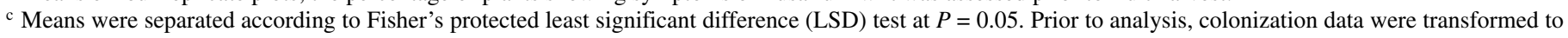
$\ln (\mathrm{CFU} / \mathrm{g}$ of tissue +1$)$, and percent wilt data were transformed into the arcsine of the square root of the proportion of wilt. 
spectively, which could be used to separate cultivars into respective resistance categories.

Field evaluation. Wilt resistance of seven watermelon cultivars evaluated was proportional to the extent of colonization in roots, crowns, or lower stems (10 $\mathrm{cm}$ long from the crown node) by F. oxysporum f. sp. niveum in both years of the experiment (Table 3). Colonization in each of the three tissue types was extremely high for the susceptible cvs. Sugar Baby and Florida Giant, low for the highly resistant cv. Royal Majesty, and intermediate for the remaining cultivars, including the moderately resistant Sugarlee. However, exceptional cases also were observed. The moderately resistant cv. Crimson Sweet had low levels of crown and stem colonization, and the highly resistant cv. Dixielee had high levels of root and crown colonization. Nevertheless, a similar correlation between percent wilt and colonization in either root or lower stem tissues was observed in each year (Fig. 2). These responses were adequately characterized by equation 1 . The effect of colonization in plant tissues accounted for 61 to $74 \%$ of the variation in percent wilt.

Using ANOVA and LSD mean comparisons, significant differences $(P \leq 0.05)$ in marketable fruit yield occurred among watermelon cultivars in each year (data not shown). Royal Majesty had the highest yield (70 t/ha) in 2001 and Sangria had the highest yield (38 t/ha) in 2002; Sugar Baby yielded the least, 7 and 0 t/ha in 2001 and 2002, respectively. Regression of tissue colonization on yield revealed a significant linear relationship $(P<0.0001)$ in each year (Fig. 3). Yield decreased with colonization in either root or stem tissues at linear rates, $a_{\mathrm{f}}$, of 9.9 to $12.7 \mathrm{t} / \mathrm{ha}$ for each unit increase in $\ln (\mathrm{CFU} / \mathrm{g}$ of tissue +1$)$. Thus, estimates of $a_{\mathrm{f}}$ varied among years and tissue types within a very narrow range, with a less than one- and half-fold difference between the largest and smallest estimate. For both years, $R^{2}$ values were high, ranging from 0.58 to 0.84 across both tissue types.

Distribution of $F$. oxysporum f. sp. niveum in field-grown plant stems. Longitudinal distribution of $F$. oxysporum f. sp. niveum within primary stems of the three cultivars Sugar Baby, Sugarlee, and Royal Majesty, representing cultivars that were susceptible, moderately resistant, and highly resistant to $F$. oxysporum f. sp. niveum race 1 , respectively, were examined under field conditions in 2001 and 2002. By the end of each season, colonization by $F$. oxysporum f. sp. niveum was detected on $100 \%$ of the primary stem length of Sugar Baby and Sugalee, but only 67\% (2001) and 60\% (2002) of the primary stem length of Royal Majesty (Fig. 4).

Percentage of colonization in the stems of each cultivar declined with increasing sampling distance from the base of stems
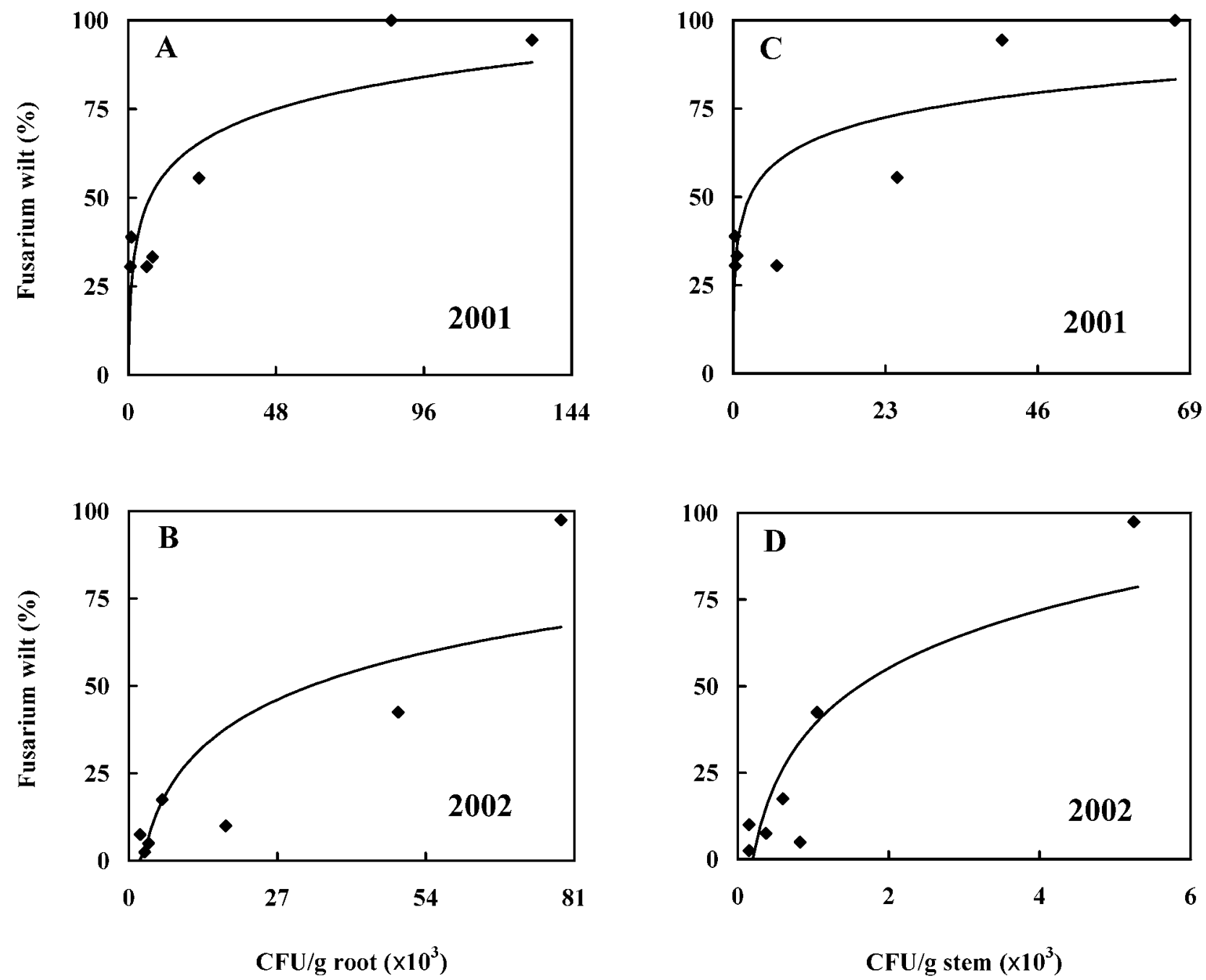

Fig. 2. Relationship between colonization $(X)$ in the $\mathbf{A}$ and $\mathbf{B}$, roots or $\mathbf{C}$ and $\mathbf{D}$, lower stems of seven watermelon cultivars by Fusarium oxysporum f. sp. niveum and incidence of Fusarium wilt $(Y)$ in A and C, 2001 and B and D, 2002 under field conditions. Observed values $(\bullet)$ are the means of four replicate plots. Three plants per plot were randomly collected at 45 days after inoculation and assayed for vascular colonization on a selective medium. Plants were inoculated individually with the culture of a race 1 chlorate-resistant marked isolate of $F$. oxysporum $\mathrm{f}$. sp. niveum 2 weeks after transplanting. Regression equations (curves) are: 2001, root, $Y=13.1 \ln (X+1)-66.2\left(R^{2}=0.70\right) ; 2001$, stem, $Y=10.1 \ln (X+1)-28.9\left(R^{2}=0.61\right) ; 2002$, root, $Y=19.5 \ln (X+1)-152.6\left(R^{2}=0.66\right)$; and 2002 , stem, $Y=24.1 \ln (X+1)-128\left(R^{2}=0.74\right)$. 
(Fig. 4). Differences in pathogen distribution along the vines among the three cultivars were characterized by differences in the parameters $a_{\mathrm{c}}$ and $b_{\mathrm{c}}$ of equation $3 ; a_{\mathrm{c}}$ (the steepness of the colonization gradient that characterized the linear rate of decrease in percent colonization with the increase in distance from the base of stem) was smaller for Sugar Baby in both years ( 0.115 and $0.124 \%$ colonization/cm, respectively) and greater for Sugarlee $(0.331$ and $0.376 \%$ colonization $/ \mathrm{cm}$, respectively) and Royal Majesty ( 0.367 and $0.375 \%$ colonization $/ \mathrm{cm}$, respectively). Thus, Sugarlee and Royal Majesty had a similar $a_{\mathrm{c}}$ value that was threefold greater than Sugar Baby. In 2001 and 2002, the upper limit of percent colonization (parameter $b_{\mathrm{c}}$ ) was similar for Sugar Baby (101 and 103\% colonization, respectively) and Sugarlee (105 and 94\% colonization, respectively), but significantly smaller for Royal Majesty (63 and 66\% colonization, respectively).

Resistance in relation to the ratio of lower stem to root colonization. The ratio of lower stem to root colonization within plants is another numerical measure to differentiate levels of resistance in watermelon. Estimated values for the ratio showed great variation among watermelon cultivars, with the range from 0.04 to 0.90 in greenhouse plants, and from 0.01 to 0.78 in fieldgrown plants. The increase of percentage of plants showing symptoms of Fusarium wilt was correlated with the increase of the ratio, which was adequately characterized by equation 4 . The in-
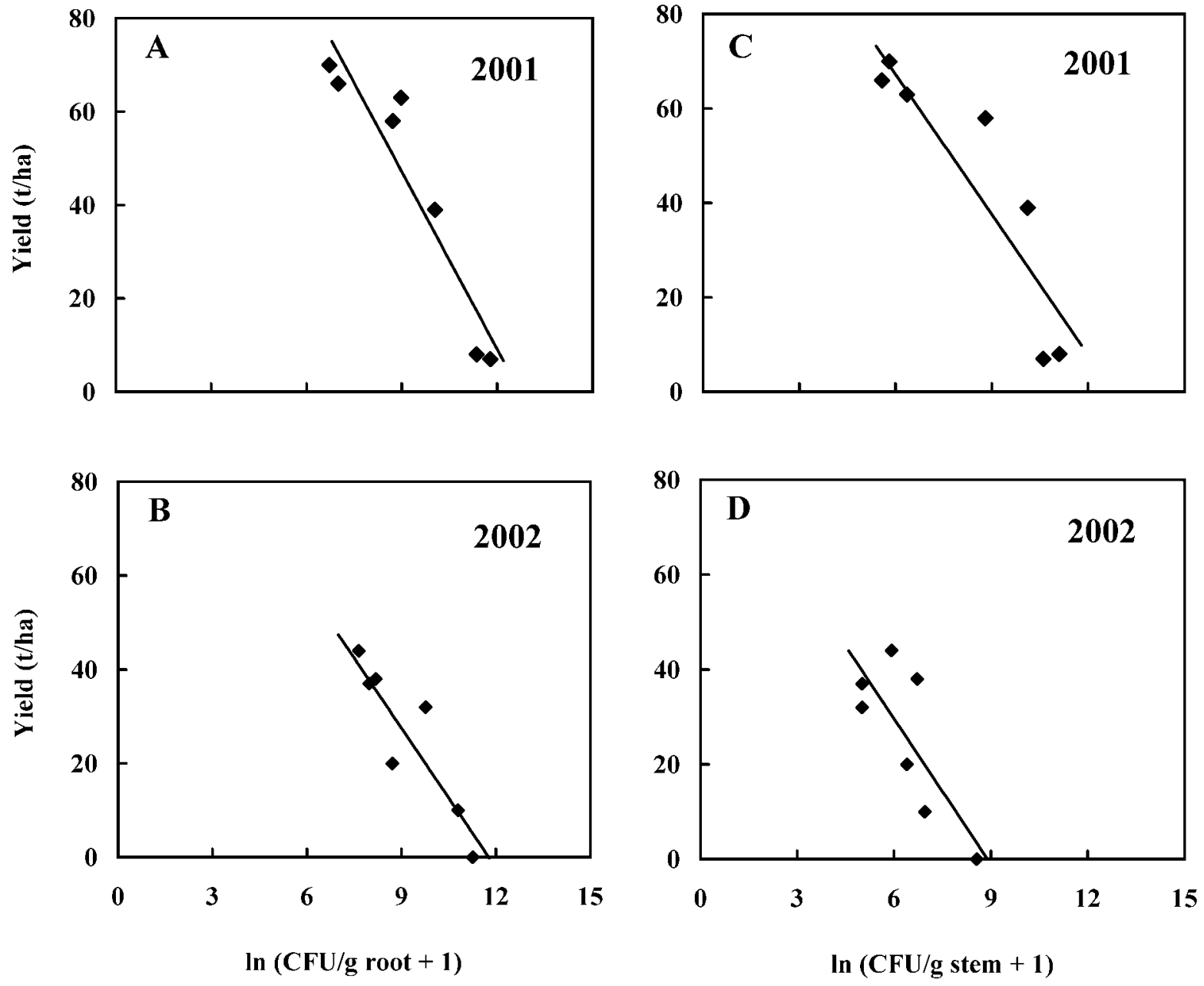

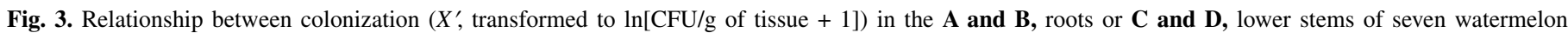

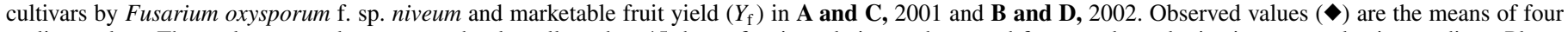

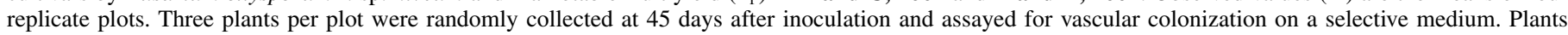

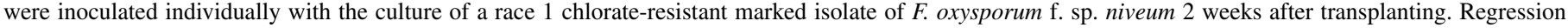

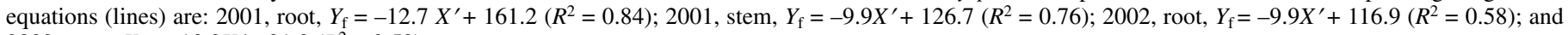
2002, stem, $Y_{\mathrm{f}}=-10.2 X^{\prime}+91.0\left(R^{2}=0.59\right)$. 
by $F$. oxysporum f. sp. niveum has been conducted $(26,29,30)$. Martyn and Netzer (30) isolated $F$. oxysporum f. sp. niveum more frequently from inoculated plants of a susceptible watermelon cultivar than a resistant accession. In a related light microscopy study, Martyn and McLaughlin (29) also observed that mycelia of $F$. oxysporum $\mathrm{f}$. sp. niveum were present in many metaxylem vessels of transverse stem sections of an infected susceptible squash cultivar but in fewer vessels of a resistant squash cultivar. When working with induced resistance in a watermelon cultivar, Martyn et al. (26) found that $F$. oxysporum f. sp. niveum still could be recovered from root and lower stem tissues of resistance-induced plants; therefore, they proposed that induced resistance was not attributed to prevention of initial penetration of the fungus but to reduced colonization in the vascular system.
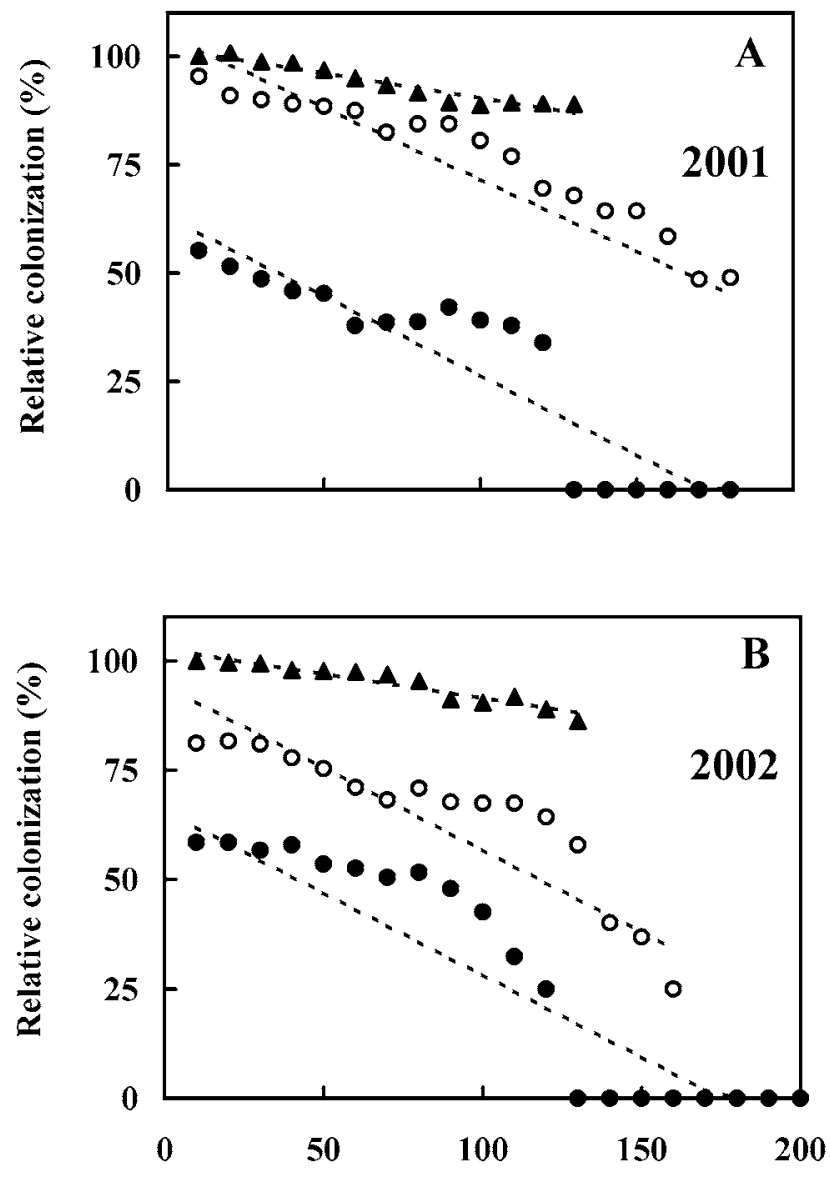

\section{Distance from the base of stem (cm)}

Fig. 4. Progressive decline of relative colonization $\left(Y_{\mathrm{c}}\right)$ by Fusarium oxysporum f. sp. niveum with increasing sampling distance $(S)$ at 10 -cm intervals from the base of primary stems of the watermelon cvs. Sugar Baby (susceptible to race $1 ; \mathbf{\Delta}$ ), Sugarlee (moderately resistant; O), and Royal Majesty (highly resistant; -) in A, 2001 and B, 2002 under field conditions. Observed values are the means of four replicate plots. A relative colonization, indicating the relative pathogen density, was calculated by dividing the average value of colonization at a specific stem section by the average value of the greatest colonization within each year (40,643 and 5,250 CFU/g of stem for 2001 and 2002, respectively), and multiplied by 100 . Three plants per plot were collected randomly at 45 days after inoculation with the culture of a race 1 chlorate-resistant marked isolate of $F$. oxysporum f. sp. niveum and assayed for vascular colonization on a selective medium. Regression equations (lines) are: $Y_{\mathrm{c}}=-0.115 S+101\left(R^{2}=0.89\right), Y_{\mathrm{c}}=-0.331 S+105\left(R^{2}=0.65\right)$, and $Y_{\mathrm{c}}=$ $-0.367 S+63\left(R^{2}=0.52\right)$ for cvs. Sugar Baby, Sugarlee, and Royal Majesty, respectively, in 2001; and $Y_{\mathrm{c}}=-0.124 S+103\left(R^{2}=0.78\right), Y_{\mathrm{c}}=-0.376 S+94$ $\left(R^{2}=0.64\right)$, and $Y_{\mathrm{c}}=-0.375 S+66\left(R^{2}=0.67\right)$ for Sugar Baby, Sugarlee, and Royal Majesty, respectively, in 2002.
Results of the current study demonstrated that $F$. oxysporum $\mathrm{f}$. sp. niveum was an effective colonizer, able to penetrate and colonize all susceptible and resistant watermelon cultivars evaluated. However, the extent of colonization by the fungus varied highly among cultivars with different levels of resistance. High levels of pathogen density were present in susceptible cultivars,
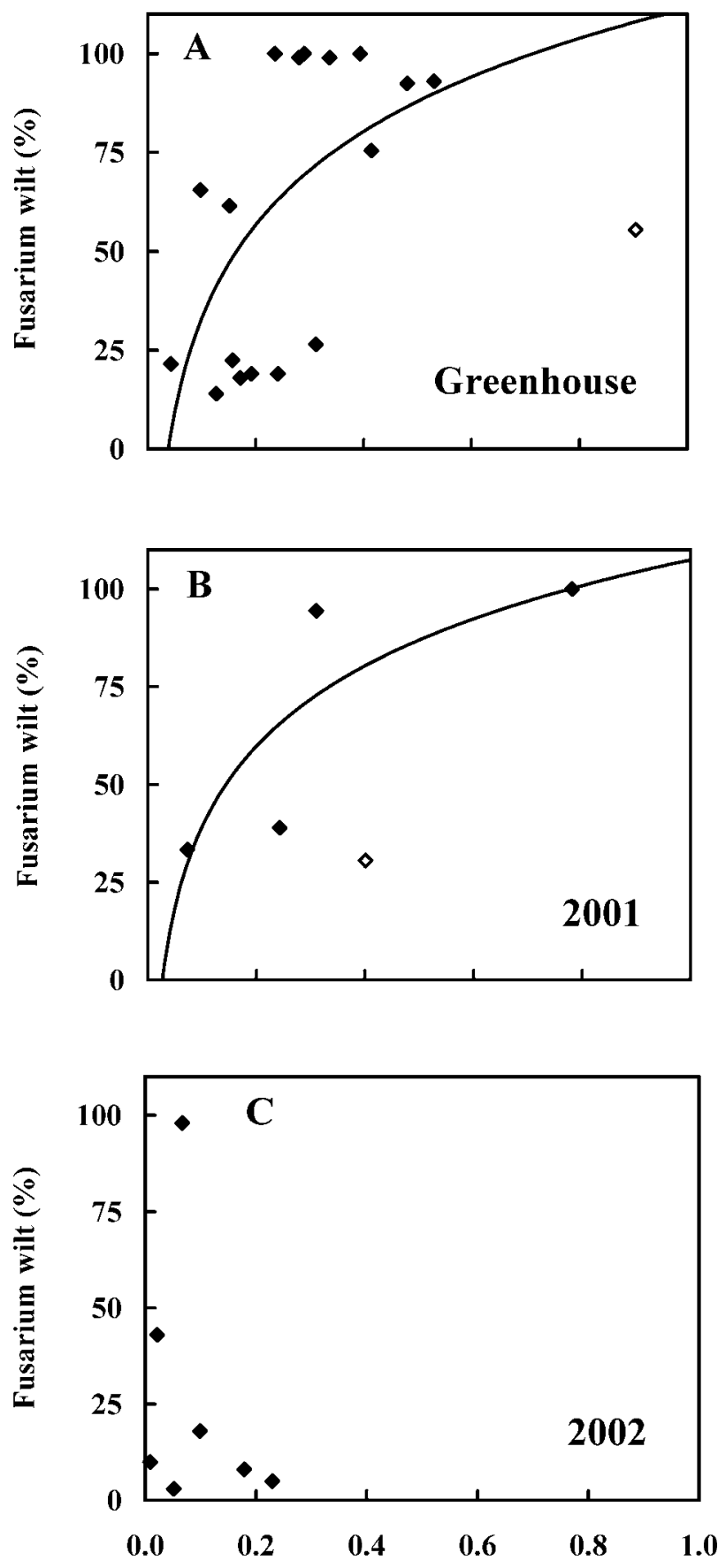

Ratio of stem to root colonization

Fig. 5. Relationship between the ratio of stem to root colonization $\left(X_{\mathrm{r}}\right)$ by Fusarium oxysporum f. sp. niveum and incidence of Fusarium wilt $(Y)$ of watermelon under A, greenhouse and B, 2001 and $\mathbf{C}, 2002$ field conditions. Observed values $(\checkmark)$ are the means of four replicates. Values for the greenhouse were averaged over two experiments. A ratio was calculated by dividing the average value of colonization for lower stem tissue by the average value of colonization for root tissue of the same plants assayed. Outliers $(\diamond)$ or two anomalous observations (>1.0 value; not shown in 2001) were not used in regression analyses. Regression equations (curves) are: greenhouse, $Y=$ $34.0 \ln X_{\mathrm{r}}+111.5\left(R^{2}=0.36\right) ; 2001, Y=29.9 \ln X_{\mathrm{r}}+107.5\left(R^{2}=0.68\right)$; and 2002, no significant relationship $(P \geq 0.81)$. 
whereas lower densities were present in highly resistant cultivars. Variation in pathogen density among cultivars occurred in a continuum from high to low, which corresponded well to the range of host resistance from susceptible to highly resistant. Such a response of host resistance to colonization by $F$. oxysporum $\mathrm{f}$. sp. niveum was characterized adequately by the curvilinear rate of the increase of Fusarium wilt incidence with increasing pathogen density in plant tissues. This response occurred in both root and lower stem tissues. In addition, the relative ratio of lower stem to root colonization by $F$. oxysporum $\mathrm{f}$. sp. niveum also was related to expression of Fusarium wilt resistance.

This article quantifies, for the first time, the continuous responses of expression of Fusarium wilt resistance to variation in pathogen density in watermelon cultivars. Our results extend previous studies in which two or few cultivars were compared using a measure of frequency of fungal isolates $(26,30)$. We evaluated a wide range of resistance to Fusarium wilt in cultivars and a large number of commercial cultivars using a measure of extent of colonization. Consequently, the form of the responses of percent wilt to pathogen colonization could be characterized in our study and the rates of these responses also could be estimated. This is the first study to use the ratio of lower stem to root colonization by $F$. oxysporum f. sp. niveum to measure and quantify resistance of Fusarium wilt in watermelon.

A functional relationship is more informative than a general qualitative trend (5); therefore, watermelon resistance to $\mathrm{Fu}$ sarium wilt was evaluated in this study by a function in addition to ANOVA and LSD mean comparisons. The logarithmic model (equation 1), in which percent wilt is constrained at high pathogen densities and the instantaneous rate of increase of percent wilt declines with density, clearly provides a simple, empirical, but biologically meaningful representation of the host resistance response over a wide range of pathogen densities. Percent wilt increases from near zero at a great rate within the range of lower densities to approximately $100 \%$ wilt at a decreased rate in higher densities. This process approximates the progressive change of apparent resistance in watermelons from highly resistant to susceptible. This also is applicable to the percent wilt response to the ratio of lower stem to root colonization (equation 4). At a ratio of zero, percent wilt approaches zero and percent wilt increases with the ratio at a decreasing rate. When the ratio is close to 1.0, percent wilt approaches the upper limit (100\% wilt).

Results of the present study reveal that resistance to Fusarium wilt can be characterized by both pathogen density in a particular tissue type (root or stem) and the ratio of stem to root colonization. The former describes the localized growth of $F$. oxysporum f. sp. niveum, whereas the latter reflects the distribution of the fungus in the xylem. Therefore, these two features encompass the whole process of vascular invasion by Fusarium wilt pathogens. However, these two need to interact together to impact the expression of host resistance. The lower the pathogen density in root or stem tissues of a cultivar with a lower ratio of stem to root colonization, the more wilt resistance in the cultivar.

Limited distribution of Fusarium wilt fungi in resistant host plants has been well established $(6,7,9,13,26,29,30)$, but measurement and quantification of the extent of secondary distribution in vascular systems are still lacking. The function of the ratio of stem to root colonization observed in our study is significant because it provides a practical means to measure cultivar response to systemic infection, or to measure the ability of the pathogen to systemically invade its host. Calculation of the ratio data in this study is based on the assumption that CFU/g of tissue values in lower stems are smaller than or equivalent to those in roots, resulting in the range of values from zero to 1.0. This was shown to be a valid assumption from our study because a decrease in pathogen density from root to lower stem tissues was observed in almost all watermelon cultivars grown in both the greenhouse and field. Additionally, there was a progressive decline of pathogen density along the vascular system from the base of stems to the top in all three cultivars examined under field conditions.

We observed inconsistencies in wilt resistance ranking and tissue colonization between greenhouse and field tests in three cultivars. Crimson Sweet exhibited moderate resistance to both Fusarium wilt and colonization in the greenhouse, but a high level of resistance in the field. Charleston Gray was susceptible and highly colonized in the greenhouse, but resistant and not highly colonized in the field. Dixielee was ranked as a highly resistant cultivar according to both greenhouse and field tests, but had unexpectedly high tissue colonization, especially in the roots. These differences in wilt resistance and the expected internal plant colonization by $F$. oxysporum f. sp. niveum suggest that tissue colonization by the Fusarium wilt pathogen, like wilt expression, is partially dependent on environmental factors such as weather and soil microorganisms. Hopkins et al. (17) observed a unique field resistance to Fusarium wilt in a Crimson Sweet monoculture of 4 to 7 years in Florida. Subsequent work done by Larkin and his co-workers $(21,22)$ demonstrated that repeated plantings of Crimson Sweet as well as Charleston Gray in the greenhouse could affect soil microflora populations and that Crimson Sweet, particularly, promoted the growth of indigenous $F$. oxysporum and fluorescent pseudomonads. They further demonstrated that this field resistance of Crimson Sweet was primarily attributed to systemic host resistance induced by nonpathogenic populations of F. oxysporum (23). The phenomena observed in our study may have resulted from increased field resistance of Crimson Sweet and Charleston Gray in response to microbially induced resistance.

Fruit yield was highly correlated with the extent of tissue colonization by $F$. oxysporum f. sp. niveum. Interestingly, fruit yield decreased with colonization at a similar linear rate (approximately $10 \mathrm{t} / \mathrm{ha}$ for each unit increase in $\ln [\mathrm{CFU} / \mathrm{g}$ of tissue]) for all tissue types and years evaluated, although yields in 2002 generally were lower than those in 2001. This may suggest a genetically governed link between colonization and yield.

Standard pathogenicity tests that evaluate wilt incidence or severity have been, and will continue to be, an essential tool to evaluate the level of Fusarium wilt resistance in watermelon. A tissue colonization assay under controlled environment conditions, however, is a collaborative method to assess wilt resistance. One advantage of this approach is to shorten the time of the growth of seedlings in the greenhouse for evaluation, which may reduce the effects of environmental factors on expression of wilt resistance. Resistance evaluation based on plant internal colonization could be completed in 1 week from inoculation to seedling sampling, whereas resistance evaluation based on external symptoms may takes 3 weeks or more following inoculation $(27,28)$.

From our results, we conclude that pathogen density in stem tissue is a better indication of resistance than pathogen density in roots. The three levels of resistance clearly were separated statistically by pathogen density in stems, but not by pathogen density in roots. Cultivar resistance ranks established in the current study generally are in agreement with previous reports $(2$, $8,28,30)$. In addition, the stem colonization assay likely would minimize possible contamination with fungal propagules on the surface of stems that would be more prevalent if root tissues were used for assay. Therefore, investigators using a colonization assay to determine resistance should consider seedling stems rather than roots. The use of Komada's medium rather than MMCPA medium for assay can save 7 to 10 days, further reducing time needed to conduct resistance evaluation.

Watermelon resistance to race 1 of $F$. oxysporum $\mathrm{f}$. sp. niveum generally was predicted by assaying pathogen density in the stems of seedlings. The stem colonization assay can aid pathogenicity screening tests for resistance evaluation. This approach also may be applicable to races 0 and 2 of $F$. oxysporum f. sp. niveum (unpublished data) and possibly for other crop-Fusarium wilt pathogen systems. 


\section{ACKNOWLEDGMENTS}

We thank C. E. Beste for helpful comments on the manuscript; anonymous referees for critical review that improved the text; and D. K. Armentrout for technical assistance.

\section{LITERATURE CITED}

1. Armstrong, G. M., and Armstrong, J. K. 1975. Reflections on the wilt fusaria. Annu. Rev. Phytopathol. 13:95-103.

2. Barnes, G. L. 1972. Differential pathogenicity of Fusarium oxysporum f. sp. niveum to certain wilt-resistant watermelon cultivars. Plant Dis. Rep. 56:1022-1026.

3. Bruton, B. D., and Damicone, J. P. 1999. Fusarium wilt of watermelon: Impact of race 2 of Fusarium oxysporum f. sp. niveum on watermelon production in Texas and Oklahoma. Subtrop. Plant Sci. 51:4-9.

4. Bruton, B. D., Patterson, C. L., and Martyn, R. D. 1988. Fusarium wilt (F. oxysporum f. sp. niveum race 2) of watermelon in Oklahoma. Plant Dis. $72: 734$.

5. Campbell, C. L., and Madden, L. V. 1990. Introduction to Plant Disease Epidemiology. John Wiley \& Sons, New York.

6. Davis, D. 1966. Cross-infection in Fusarium wilt diseases. Phytopathology 56:825-828.

7. Elgersma, D. M., MacHardy, W. E., and Beckman, C. H. 1972. Growth and distribution of Fusarium oxysporum f. sp. lycopersici in near-isogenic lines of tomato resistant or susceptible to wilt. Phytopathology 62:1232-1237.

8. Elmstrom, G. W., and Hopkins, D. L. 1981. Resistance of watermelon cultivars to Fusarium wilt. Plant Dis. 65:825-827.

9. Gao, H., Beckman, C. H., and Mueller, W. C. 1995. The rate of vascular colonization as a measure of the genotypic interaction between various cultivars of tomato and various formae speciales or races of Fusarium oxysporum. Physiol. Mol. Plant Pathol. 46:29-43.

10. Gordon, T. R., Jacobson, D. J., May, D. M., Tyler, K. B., and Zink, F. W. 1990. Fruit yield, disease incidence, and root colonization of hybrid muskmelons resistant to Fusarium wilt. Plant Dis. 74:778-781.

11. Gordon, T. R., and Martyn, R. D. 1997. The evolutionary biology of $\mathrm{Fu}$ sarium oxysporum. Annu. Rev. Phytopathol. 35:111-128.

12. Gordon, T. R., and Okamoto, D. 1990. Colonization of crop residue by Fusarium oxysporum f. sp. melonis and other species of Fusarium. Phytopathology 80:381-386.

13. Gordon, T. R., Okamoto, D., and Jacobson, D. J. 1989. Colonization of muskmelon and nonsusceptible crops by Fusarium oxysporum f. sp. melonis and other species of Fusarium. Phytopathology 79:1095-1100.

14. Hadar, E., Katan, J., and Katan, T. 1989. The use of nitrate-nonutilizing mutants and a selective medium for studies of pathogenic strains of Fusarium oxysporum. Plant Dis. 73:800-803.

15. Hawkins, L. K., Dane, F., Kubisiak, T. L., Rhodes, B. B., and Jarret, R. L. 2001. Linkage mapping in a watermelon population segregating for $\mathrm{Fu}-$ sarium wilt resistance. J. Am. Soc. Hortic. Sci. 126:344-350.

16. Henderson, W. R., Jenkins, S. F., and Rawlings, J. O. 1970. The inheritance of Fusarium wilt resistance in watermelon, Citrullus lanatus (Thunb.) Mansf. J. Am. Soc. Hortic. Sci. 95:276-282.

17. Hopkins, D. L., Larkin, R. P., and Elmstrom, G. W. 1987. Cultivarspecific induction of soil suppressiveness to Fusarium wilt of watermelon. Phytopathology 77:607-611.

18. Huisman, O. C. 1988. Colonization of field-grown cotton roots by pathogenic and saprophytic soilborne fungi. Phytopathology 78:716-722.

19. Katan, J. 1971. Symptomless carriers of the tomato Fusarium wilt pathogen. Phytopathology 61:1213-1217.

20. Komada, H. 1975. Development of a selective medium for quantitative isolation of Fusarium oxysporum from natural soil. Rev. Plant Prot. Res. 8:114-124.

21. Larkin, R. P., Hopkins, D. L., and Martin, F. N. 1993. Ecology of Fusarium oxysporum $\mathrm{f}$. $\mathrm{sp}$. niveum in soils suppressive and conducive to Fusarium wilt of watermelon. Phytopathology 83:1105-1116.

22. Larkin, R. P., Hopkins, D. L., and Martin, F. N. 1993. Effect of successive watermelon plantings on Fusarium oxysporum and other microorganisms in soils suppressive and conductive to Fusarium wilt of watermelon. Phytopathology 83:1097-1105.

23. Larkin, R. P., Hopkins, D. L., and Martin, F. N. 1996. Suppression of Fusarium wilt of watermelon by nonpathogenic Fusarium oxysporum and other microorganism recovered from a disease-suppressive soil. Phytopathology 86:812-819.

24. Martyn, R. D. 1987. Fusarium oxysporum f. sp. niveum race 2: A highly aggressive race new to the United States. Plant Dis. 71:233-236.

25. Martyn, R. D. 1996. Fusarium wilt of watermelon. Pages 13-14 in: Compendium of Cucurbit Diseases. T. A., Zitter, D. L., Hopkins, and C. E., Thomas, eds. The American Phytopathology Society, St. Paul, MN.

26. Martyn, R. D., Biles, C. L., and Dillard, E. A., III. 1991. Induced resistance to Fusarium wilt of watermelon under simulated field conditions. Plant Dis. 75:874-877.

27. Martyn, R. D., and Bruton, B. D. 1989. An initial survey of the United States for races of Fusarium oxysporum f. sp. niveum. HortScience 24:696-698.

28. Martyn, R. D., and McLaughlin, R. J. 1983. Effects of inoculum concentration on the apparent resistance of watermelons to Fusarium oxysporum f. sp. niveum. Plant Dis. 67:493-495.

29. Martyn, R. D., and McLaughlin, R. J. 1983. Susceptibility of summer squash to the watermelon wilt pathogen (Fusarium oxysporum f. sp. niveum). Plant Dis. 67:263-266.

30. Martyn, R. D., and Netzer, D. 1991. Resistance to races 0, 1, and 2 of Fusarium wilt of watermelon in Citrullus sp. PI-296341-FR. HortScience 26:429-432.

31. McClurg, C. A., Beste, C. E., Bouwkamp, J. C., Rouse, R. J., Everts, K. L., Linduska, J. L., Brown, A. E., and Dively, G. P. 2001. Commercial Vegetable Production Recommendations. Md. Coop. Ext. Serv. Circ. EB236.

32. Neter, J., Kutner, M. H., Nachtsheim, C. J., and Wasserman, W. 1996. Applied Linear Regression Models. Times Mirror Higher Education Group, Inc., Chicago.

33. Netzer, D. 1976. Physiological races and soil population level of Fusarium wilt of watermelon. Phytoparasitica 4:131-136.

34. Netzer, D., and Weintall, C. 1980. Inheritance of resistance in watermelon to race 1 of Fusarium oxysporum f. sp. niveum. Plant Dis. 64:853-854.

35. Puhalla, J. E. 1985. Classification of strains of Fusarium oxysporum on the basis of vegetative incompatibility. Can. J. Bot. 63:179-183.

36. Reid, J. 1958. Studies on the fusaria which cause wilt in melon. Can. J. Bot. 36:393-413.

37. Steel, R. G. D., Torrie, J. H., and Dickey, D. A. 1997. Principles and Procedures of Statistics: A Biometrical Approach. McGraw-Hill, Inc., New York.

38. Stover, R. H., and Waite, B. H. 1953. An improved method of isolating Fusarium spp. from plant tissue. Phytopathology 43:700-701.

39. Stromberg, E. L., and Corden, M. E. 1977. Fungitoxicity of xylem extracts from tomato plants resistant or susceptible to Fusarium wilt. Phytopathology 67:693-697.

40. Swanson, T. A., and Van Gundy, D. D. 1985. Influences of temperature and plant age on differentiation of races of Fusarium oxysporum f. sp. tracheiphilum on cowpea. Plant Dis. 69:779-781.

41. Windels, C. E. 1992. Fusarium. Pages 115-128 in: Methods for Research on Soilborne Phytopathogenic Fungi. L. L. Singleton, J. D. Mihail, and C. M. Rush, eds. The American Phytopathology Society, St. Paul, MN.

42. Zhou, X. G., and Everts, K. L. 2001. First report of the occurrence of Fusarium oxysporum f. sp. niveum race 2 in commercial watermelon production areas of Maryland and Delaware. Plant Dis. 85:1291.

43. Zhou, X. G., and Everts, K. L. 2003. Races and inoculum density of $\mathrm{Fu}$ sarium oxysporum $\mathrm{f}$. sp. niveum in commercial watermelon fields in Maryland and Delaware. Plant Dis. 87:692-698.

44. Zhou, X. G., and Everts, K. L. 2003. Watermelon colonization by Fusarium oxysporum f. sp. niveum and quantification of Fusarium wilt resistance. (Abstr.) Phytopathology 93:S95.

45. Zhou, X. G., Everts, K. L., and Armentrout, D. K. 2002. Resistance of watermelon cultivars to Fusarium wilt and root colonization, 2001. Biol. Cult. Tests (online) 17:V27. DOI:10:1094/BC17.

46. Zhou, X. G., Everts, K. L., and Armentrout, D. K. 2003. Resistance of seeded (diploid) watermelon cultivars to Fusarium wilt, 2002. Biol. Cult. Tests (online) 18:V004. DOI:10:1094/BC18. 